\section{Economic aspects of peacekeeping in Iraq: what went wrong?}

Bassam Yousif

$\mathrm{P}$ rospects for Iraq's economy are bleak: unemployment remains high and the post-war rebuilding effort has slowed to a trickle, weighed down by chronic instability. Rising oil prices increased GDP in 2004 and 2005. But an oilinduced rise in GDP will not necessarily bring about a general rise in incomes, as the oil sector - although it accounts for most of GDP and almost all exports and government revenue - employs only 1 percent of the labor force. ${ }^{1}$ To raise general living standards, oil income needs to be converted into increased employment and output in sectors with high social rates of return. Given the financial, technical, and security constraints, aggravated by Coalition Provisional Authority (CPA) and Iraqi government economic policies, this will not be easy to achieve.

This article reviews key CPA post-war policies and their effects, and proposes and discusses a set of alternative policies that would be better suited to improve Iraqi living standards and help secure peace.

\section{CPA polices}

Coalition policies launched perhaps the most abrupt and sweeping liberalization of markets attempted anywhere, the goal being to improve the efficiency in the allocation of resources and to thus expand output and incomes. ${ }^{2}$ In the labor market, roughly half a million state employees (about 8 percent of the labor force) were fired, mostly as a result of the dissolution of the Iraqi army but also through "de-Ba'athification." 3 Workers retained in the public sector nonetheless received large salary increases, six-fold on average. ${ }^{4}$ The CPA also carried out reforms in currency, foreign trade, taxation, and capital markets: a new currency was introduced, import tariffs were slashed, ${ }^{5}$ corporate tax rates were reduced, and, to encourage outside investment, foreign companies were allowed to acquire Iraqi assets (except in the oil sector) and to repatriate profits. The CPA also planned to privatize state-owned enterprises, a plan blocked by the 1949 Geneva Convention that prevents occupying powers from disposing of assets they do not own. Unable to privatize, the CPA froze the bank accounts and subsidies of public firms, thereby denying them working capital. Finally, despite United Nations advice to the contrary, the CPA ended agricultural subsidies.

The logic of these policies was to induce productive factors - capital and labor in particular - to flow to activities that have a high social rate of return. For this to be realized, however, enforceable property rights and high rates of investment are required. Capitalists are unlikely to invest if they perceive their investments to be insecure. Existing capital is sector specific and difficult to transfer from activities with low social rates of return to the desired high return activities. New investments allow resources to flow to high return activities without having to rely on transfers from less efficient sectors. ${ }^{6}$ In Iraq, structural difficulties prevented CPA policies from realizing high rates of capital formation in high social return sectors.

\section{Structural difficulties}

The capacity of the Iraqi economy to absorb investments had been diminishing for some time ${ }^{7}$ and was most likely at a low following the United States/United Kingdom occupation in 2003. According to the United Nations, the 1991 Gulf war "relegated [Iraq] to the pre-industrial age, but with all the disabilities of postindustrial dependency on an intensive use of energy and technology." The economic sanctions during the 1990s, even when later relaxed under the oil-forfood program, prevented any meaningful rebuilding, and facilities and equipment in most sectors, including oil, continued to deteriorate. The reduction in oil exports induced large declines in incomes per capita so that Iraq, once securely in the middle-income category (as defined by the World Bank), was relegated to lowincome status. Even before the 2003 invasion, Iraq's GDP per capita is estimated to have declined to US\$596 in 2002, ${ }^{9}$ only slightly higher than the average Gross National Income (GNI) for low-income economies, which stood at US\$450 in 2003. ${ }^{10}$ The penury encouraged the emigration of large numbers of skilled and technical personnel seeking better livelihoods abroad. The "brain drain" has continued since the occupation. Insecurity, violence, and the firing of senior Ba'thists, many of whom were managers and professionals, induced skilled labor to flee Iraq. ${ }^{11}$ This, along with the physical damage sustained during the invasion, means that the occupying forces took over a country whose physical infrastructure and skills level was greatly depleted. Even under secure conditions, the Iraqi economy's ability to absorb investments would have been limited.

\section{Policy outcomes}

In the context of Iraq's weak ability to absorb investments, CPA measures were put into action. Some of the reforms, especially the currency reforms and debt relief, were praiseworthy. But the central aim of the measures - to induce capital and labor to flow to high-return activities - remains illusive. The promotion of employment and capital formation has run aground.

The army's demobilization raised unemployment and undoubtedly contributed to the security crisis. The most reliable data from surveys of Iraq's Central 
Statistical Organization. They reveal that unemployment climbed sharply from 16.8 percent in $1997^{12}$ (at the depth of economic distress under economic sanctions, before the implementation of the oil-for-food program) to 28.1 percent in late $2003,{ }^{13}$ and then declined only marginally to 26.8 percent in the first half of $2004 .{ }^{14}$ Despite the slight decline in early 2004, independent estimates of the unemployment rate are higher and average from 25 to 40 percent for the period of January to November 2005. ${ }^{15}$

Joblessness is not the only reason for Iraq's instability but has aggravated rather than ameliorated the security problem.

Demobilization raised unemployment for young urban males. ${ }^{16}$ Joblessness is not the only reason for Iraq's instability, but the high unemployment has aggravated rather than ameliorated the security problem.

Joblessness, disproportionately concentrated among young males, has undoubtedly impelled some to seek work in militias or engage in crime. As one frustrated jobseeker in a poor district of Baghdad explained:

“I haven’t been working for the last two weeks. If I stay like this for another week, my family will starve; and if someone comes with US\$50 and asks me to toss a grenade at the Americans, I'll do it with pleasure.”17

Reconstruction activities have absorbed an insufficient amount of the idle labor because, in general, they have utilized capital-intensive techniques. Construction activities are typically characterized by substantial opportunities to substitute labor for capital. ${ }^{18}$ But plentiful Iraqi labor has been under-utilized in reconstruction, as U.S. firms (mainly in charge of reconstruction) do not face Iraqi relative factor prices. The cost of hiring Iraqis is relatively high because they are considered to be a security risk. ${ }^{19}$ Consequently, it makes little sense for U.S. contractors to hire local labor.

But what is rational for individual contractors does not necessarily benefit the rebuilding effort as a whole. Unemployment and the resultant insecurity have seriously hampered the reconstruction effort. Unwillingness to hire Iraqi labor transfers, but does not solve, the security problem. Indeed, violence and instability have resulted in the destruction of productive assets, restrained investment, and delayed and increased the cost of rebuilding. Few foreign investors have been willing to do work at these high levels of risk. The IMF notes that none of the foreign banks that were given licenses to operate have opened for business. ${ }^{20}$ And, investments made by Iraqis and U.S.-funded contractors have proceeded slowly and at increased costs.

The binding constraint on investment in Iraq has not been availability of funds but the economy's low ability to absorb investments, exacerbated by the violence. U.S.-financed rebuilding progressed at a glacial pace in the first 18 months of occupation. By 15 September 2004, only US\$1.1 billion out of the US\$18.4 billion allocated by the U.S. Congress for reconstruction had been spent. Only US\$16 million of the US $\$ 4.2$ billion earmarked for water and sanitation projects had been utilized, and only a mere US\$2 million of the US\$786 million for health care had been spent. ${ }^{21}$ It is no wonder that the majority of Iraqis polled in May 2004 thought that rebuilding had yet to begin. ${ }^{22}$

Reconstruction accelerated in 2005: a total of US\$8.6 billion has been spent as of 28 September 2005, including US\$390 million on water and sanitation projects and US\$242 million on health. ${ }^{23}$ But total expenditure falls substantially short of the allocated funds and gives a misleadingly exaggerated image of the actual reconstruction. Much of the U.S.-financed spending on rebuilding has been unrelated to civilian reconstruction. As a result of rampant insecurity, the U.S. has diverted funds initially allocated to civilian rebuilding toward security and law enforcement which, as of 28 September 2005, received US\$3.6 billion or more than two-fifths of the US $\$ 8.6$ billion total. ${ }^{24}$ Precisely because security-related activities are comparatively labor-intensive - they engage a fairly large number of Iraqis and do not place great demands on physical infrastructure - it has been easy to spend these monies.

In contrast, civilian reconstruction activities have been highly capital intensive. As a result, U.S. spending on civilian rebuilding, including electricity, oil, civil society, roads and bridges, education, health, transport and sanitation, amounted to only about US $\$ 5$ billion, as of 28 September $2005 .{ }^{25}$ Yet even this small amount overstates the extent of U.S.-funded capital formation, as, for a number of reasons, the real value of spending is lower than these figures indicate. First, according to a Center for Strategic and International Studies report, fraud and mismanagement are responsible for soaking up an estimated 15 percent of reconstruction expenditure. ${ }^{26}$ Second, the costs of reconstruction have swelled because a large portion - two-thirds in term of value in $2003^{27}$ - of the contracts were awarded to U.S. companies on a non-competitive basis. And third, according to the IMF, an astounding 30-50 percent of the total value of contracts is spent by contractors directly on security and insurance. ${ }^{28}$ For these reasons, the value of capital formation is much lower than even the small total for U.S.-funded civilian reconstruction suggests. The Interim Governing Council spent US\$1.87 billion on reconstruction in $2003^{29}$, US\$3.5 billion in 2004, ${ }^{30}$ and planned to spend more in 2005, but this is a fraction of the US\$17.5 billion that the World Bank and United Nations estimate is required to restore infrastructure and public services to preinvasion levels. ${ }^{31}$ And the last estimate assumes conditions of relative peace. 


\section{Present and prospective outcomes}

Along with joblessness and insecurity, there has been a decline in the goodsproducing sectors of the economy and evidence of deterioration in human development outcomes. Investment difficulties have delayed the restoration of basic services. The January 2006 level of electricity generation was 15 percent lower than the pre-invasion level. In Baghdad, electricity output from January to April 2005 was two-fifths of its pre-occupation level. ${ }^{32}$ Energy-intensive manufacturing activities are consequently at a standstill, while competition from international food producers has resulted in a decline in domestic agricultural output. $^{33}$ The lack of electricity also resulted in diminished access to safe water and to a rise in water-borne disease and child malnutrition which, according to Iraqi government and United Nations studies, almost doubled between March 2003 and November $2004^{34}$ - this despite the removal of economic sanctions. Mortality rates increased during the invasion period of March/April 2003 and, as of late 2004, had not receded. Deaths have occurred as a result of violence, frequently from coalition military action and also from crime. ${ }^{35}$

None of this has helped the new Iraqi government establish control and legitimacy in the country. CPA measures, with whom the new Iraqi leaders are inevitably associated, have generated hostility from broad sections of the population. Moreover, the CPA's disbursement of Iraq's public funds (generated from the sale of oil) on recurrent items that will be hard to curtail in future, e.g., salary increases to public employees without compensating increases in revenue or reductions of expenditure elsewhere, has greatly reduced the financial independence of the new government. In fact, despite the rise in the price of its exported oil, Iraq is running a large fiscal deficit. ${ }^{36}$ This has constrained the amount that the Iraqi administration is able to devote to its own priorities. In the words of Philippe Le Billon, “the U.S. sought to buy Iraqi friends with Iraqi money, leaving little behind for the future Iraqi government to buy friends of its own."37 Likewise, lacking the necessary investment finance that the crucial oil sector urgently requires, the new Iraqi administration appears to be close to succumbing to pressure from the U.S. and U.K. governments to privatize part of the country's oil industry by signing so-called production sharing agreements. These agreements are long-term (25 to 40 year) contracts between the Iraqi government and multinational oil companies. While they provide investments finance for the oil sector in the short-term, the contracts are expected to cost Iraq between US\$74 billion and US\$194 billion over 30 years. $^{38}$

It would be unfair to blame CPA policies for all of Iraq's economic difficulties: as noted, some CPA measures were laudable and many of the economic challenges that Iraq faces are long-term, structural, and often pre-date the CPA. Still, CPA polices exacerbated rather than abated the difficulties. Nor have the policy choices of the new Iraq administration been any more creditable, even when one considers in mitigation the financial difficulties and the enormous political and security challenges that the new government faces - it does not control even most of the urban areas of the country. The new administration has continued to neglect agriculture (much like Saddam and the CPA), has acted clumsily and ineffectively in changing the composition of its expenditure, and is plagued by corruption.

\section{Alternative policies}

A change in the focus of public policies is needed in Iraq, away from rapid liberalization toward an agenda that emphasizes human development, that is, measures that perceptibly and fairly rapidly raise the living standards of the population, especially of the poor, improve security, and increase the economy's aptitude to absorb investments for rebuilding. Such an agenda might include the following policies.

A program of guaranteed public employment

A program of guaranteed public employment in labor-intensive work projects, at relatively low wages to minimize labor market distortions, ${ }^{39}$ might include activities ranging from rubbish collection to irrigation network repairs to basic construction activities. This is not a novel proposal. ${ }^{40}$ In fact, some U.S. military commanders implemented similar schemes but were forced to abandon them when the allocated funds were exhausted. ${ }^{41}$ Such an employment plan would not be a public assistance program but a public investment venture, where projects could be carefully selected and only those with a relatively high social rate of return would be undertaken.

This type of program would work to expand the ability of the economy to absorb capital formation in at least three ways. First, it would build or repair productive assets such as roads,
Employment plans are not public assistance programs but investment ventures, expanding the economy's ability to absorb capital. railways, hospitals, and irrigation networks. Because the program would rely on an under-utilized resource (labor), capital formation is likely to be easier to achieve than through capital-intensive techniques that place great demands on a depleted physical infrastructure. Second, as the resulting public infrastructure would make it easier and cheaper to move goods and production factors, the employment scheme would reduce the cost of private sector investment. Instead of crowding-out of private investment, the employment scheme would result in crowding-in. The program also would engage 
a large number of unskilled or semi-skilled laborers with few employment alternatives, including some who would otherwise engage in crime or be attracted to work in militias. Thus, third, the program is likely to promote security and hence lower the costs of reconstruction.

A guaranteed work scheme is also likely to be pro-poor, providing productive employment and income for the most economically vulnerable in society, those with the lowest skills and incomes. The program is unlikely to attract educated (secondary school and university level) workers who are typically better-off and less vulnerable. Although in practice no one ought to be excluded, the educated in Iraq, as elsewhere in the Middle East, are more likely to queue for better or "respectable" jobs where the average skills requirements tend to be higher. ${ }^{42}$ The employment scheme would probably result in a significant reduction in joblessness because more than half the unemployed in Iraq are low-skilled workers (with only a primary level degree or less). ${ }^{43}$

\section{Promotion of the agricultural sector}

Promotion of Iraq's agricultural sector through improvements in agricultural infrastructure and possibly through some subsidization of output is another option. Under Saddam, a plethora of input subsidies were given to farmers in exchange for the sale of output of grains to the state at deliberately repressed prices. The food, in turn, was sold to the public at nominal prices in a non-targeted rations program. Although this production and distribution system was characterized by some inefficiency, it probably averted a famine during economic sanctions as it allowed people access to "entitlements" of food through rations. ${ }^{44}$ After the removal of Saddam and the sanctions, the CPA ended farm subsidies, reasoning that food could now be freely imported. But in the absence of the subsidies, Iraqi farmers have been unable to compete, either in terms of quality or price, with subsidized Australian or U.S. grain, causing many to abandon farming.

Labor-intensive works projects could repair drainage and irrigation systems, rural roads (essential to transport goods to market), and the extension of services, including credit, could go a long way toward making local agriculture more competitive. Another way to do so would be to re-institute some subsidization. The resulting gain, in terms of employment, in this overwhelmingly labor-intensive sector may well outweigh the costs in terms of efficiency.

Reorientation of reconstruction expenditure

A reorientation of reconstruction expenditure away from large, capital-intensive infrastructure projects, whose benefits have a long maturation period, to smaller projects, whose positive effects are more immediate, and from central government to local authorities is also advised. Some expenditure on such large projects, such as electricity generation, is of course essential. ${ }^{45}$ Where possible, however, preference should be shown to smaller projects, such as minor repair of buildings, roads, and sewage systems. Not only are these activities typically labor-intensive, they are also often associated with a high social rate of return.

Parallel to the re-orientation in spending, a decentralization of decision-making is desirable. Post-conflict reconstruction has historically had better success when it has involved large numbers of local personnel and a sense of local participation, both of which have been lacking in post-war Iraq thus far. ${ }^{46}$ The involvement of local communities, in contrast to the top-heavy solutions that the CPA and Saddam favored, ${ }^{47}$ helps to identify development priorities and could yield future gains in terms of the growth of nascent institutions of civil society.

Avoidance of hasty privatization of state assets

It is often casually assumed that private ownership yields socially more efficient outcomes than public ownership. Yet even a modest review of the evidence suggests that privatization does not always promote efficiency
It is often assumed that private ownership yields more efficient outcomes than public ownership. Yet privatization does not always promote efficiency and is sometimes harmful.
While the sale of public assets can be attractive to cash-strapped governments - it is an easy way to both reduce outlays to loss-making firms and generate revenue - a number of issues are worth considering. First, is there a social interest in retaining the public asset in question ${ }^{49}$ Profit or loss are not the correct criteria with which to determine efficiency, as public enterprises are concerned with social costs and benefits that may deviate considerably from market prices. A lossmaking public enterprise may thus be socially efficient; if so, it should be retained. Second, even if the sale of state assets is expected to promote efficiency, it may be prudent to delay the sale because the social costs in terms of increased unemployment, worsened income distribution, and aggravated social instability could outweigh the gains in the short to medium-term. Insisting on the immediate sale of state assets in Iraq, as envisioned by the CPA, is likely to be self-defeating: It would further swell joblessness and insecurity and promote resistance to future reform. Finally, if the retention of state enterprises promotes neither the goals of economic efficiency nor equity, then improving their performance by increasing revenue or reducing cost - as opposed to outright sale - is an option, although care ought to be taken to avoid mass redundancies. These issues are especially relevant in reference to the advocated de facto privatization of Iraq's vital oil sector. 
Prudence in tackling costly subsidies

Iraq's financial dilemma stems in part from costly food and petroleum subsidies. The first is a leftover from the sanctions era, and the latter has been around for decades. Both have come to be seen as entitlements by the public. The petrol subsidy is especially costly. Because of damaged refining capacity, Iraq can satisfy only about half of its domestic gasoline demand, requiring the remainder to be imported at high international prices. Along with subsidies for electricity, those for food and petrol are projected to cost the state, in 2006, US\$7 billion in increased expenditure, or roughly one-fifth of the central government budget. ${ }^{50}$

Because of the expense, and distortions arising from the subsidies, the IMF, along with others, has pushed for their reduction or removal. But ending the subsidies will disproportionately harm the poor and may engender popular unrest. Fortunately, the subsidies can be reformed in such a way that they both protect the food entitlements of the neediest and avoid mass protests and any ensuing instability. Regrettably, this is not what is happening. Riots over reductions in subsidies, in the Middle East and elsewhere, have less to do with prices than with equity: declines in subsidies that are perceived to be fair and equitable rarely elicit a violent response. ${ }^{51}$ In contrast, when the Iraqi government abruptly quintupled the price for petrol at the end of 2005, violent protests ensued. The same or greater budgetary savings could have been achieved by offering some petrol at a low price as part of the existing rations provisions, while requiring that anything beyond that be purchased at much higher market prices. This would have shown more concern with issues of equity while shielding lower-income consumers. Equally, the cost of the food rations program could be significantly reduced through self-selected targeting: offering lower-quality grain that is attractive to the poor as opposed to the high-quality imported grain that the Iraqi government currently favors. ${ }^{52}$ This would have the added advantage of stimulating domestic agriculture that produces lower quality grains.

\section{Conclusion}

Careful handling of the issues surveyed here, along with the implementation of the noted initiatives, would enhance the lives of Iraqis. They would improve the employment and security picture, alleviate investment bottlenecks, and aid reconstruction. In addition, the involvement of large numbers of Iraqis in their nation's rehabilitation - in contrast to present efforts from which many Iraqis feel excluded $^{53}$ - would be hugely beneficial in terms of political legitimacy and help to lay the foundation for an open economy and society.

Such measures may also prove essential politically. No government can survive repeat failure in providing the most basic public good of all: peace. Paradoxically, the turmoil thus affords the new Iraqi administration an opportunity to enhance its legitimacy by sponsoring people-centered policies that promote both economic development and security.

The obstacles to the implementation of such a program are nevertheless considerable. The program would likely meet stiff opposition from international lenders such as the World Bank and IMF and may need to be mostly domestically financed. Given that the Iraqi government is running a large fiscal deficit and that most of the U.S. funds devoted to reconstruction have been contracted (even though only a fraction has been spent), there are no excess funds available Substantial changes in the composition of existing expenditure as well as increased taxation - never easy even at the best of times - may be required to successfully carry out this program. Regardless of the obstacles, economic policies that promote both development and security are the only solution for Iraq. Without them, the prospects for Iraq's economy and its people will remain bleak.

\section{Notes}

Bassam Yousif is an economics professor at Indiana State University, Terre Haute, IN. He may be reached at byousif@isugw.indstate.edu.

1. Foote, et al. (2004, p. 50).

2. For a detailed appraisal of these policies, see Yousif (2006).

3. Foote, et al. (2004, p. 55).

4. ICG (2004, p. 1)

5. Foote, et al. (2004, p. 64).

6. See Griffin (1996).

7. For a discussion of the difficulties that Iraq faced in terms of absorbing investments in the 1970s and 1980s see Alnasrawi (1994).

8. Quoted in Alnaswari (2002, p. 67).

9. IMF (2003, p. 22).

10. World Bank (2004, p. 257).

11. See, e.g., Janabi (2004) and Struck (2006).

12. Calculated from CSO (undated, pp. 39, 57-60). 


\section{Howley (2004, p. 3).}

14. UPI (2004). At first glance these unemployment figures vary markedly from that of UNDP (2005) which estimates the rate of unemployment to be 10.5 percent. The discrepancy is not the result of sampling error but of varying definitions of unemployment. When the definitions are reconciled, the UNDP unemployment rate rises to 22.5 percent, broadly comparable to the CSO estimates (see Sletten, 2005).

15. Brookings Institution (undated)

16. Coalition officials claim that the Iraqi armed forces disintegrated during the invasion and so the formal act of dissolution was a mere formality. This, along with other justifications for the army's disbanding, is unconvincing (see Yousif, 2006).

17. Quoted in Foote, et al. (2004, p. 58).

18. Little, Scitovsky, and Scott (1970).

19. As one Coalition procurement officer put it, "from a force protection standpoint, Iraqis are more vulnerable to bad guy influence” (quoted in ICG, 2004, p. 17).

20. $\operatorname{IMF}(2005$, p. 7).

21. Weisman (2004).

22. ICG (2004, p. 2)

23. US (2005, p. 23)

24. US (2005).

25. Calculated from US (2005).

26. CSIS (2004, p. 3). For an analysis of the role of corruption in Iraq's reconstruction, see Le Billon (2005).

27. Le Billon (2005, p. 696)

28. $\operatorname{IMF}(2005$, p. 7)

29. ICG $(2004$, p. 2)

30. Calculated from IMF (2005a, pp. 8, 11)

31. ICG (2004, p. 2)

32. Brookings Institution (undated).
33. Pollack (2006).

34. Vick (2004).

35. Roberts, et al. (2004) suggest that the war resulted in 100,000 civilian deaths.

36. For estimates of the deficit see IMF (2005, pp. 31-32)

37. Le Billon (2005, p. 696).

38. Mullit (2006); ICG (2004, pp. 1-10).

39. Griffin and McKinley (1994).

40. Public employment schemes have been used successfully in India and Bangladesh (see Griffin and McKinley, 1994, chapter 5).

41. ICG (2004, p. 18)

42. See Richards and Waterbury (1998, pp. 133-144). In Iraq more than two-thirds of the unemployed live with, and are presumably to some extent supported by, working family-members. Also see Sletten (2005).

43. Calculated from UNDP (2005, vol. 1. p. 122).

44. For a detailed discussion of the food rations program, see Gazdar and Hussain (2002)

45. This is especially the case as more than 90 percent of households receive electricity through electrical networks (see UNDP, 2005, vol. 2, p. 16).

46. ICG (2004).

47. Le Billon (2005).

48. See, e.g., Ram Mohan (2005), Omran (2004), and Fine (1997).

49. See Griffin and McKinley (1994, chapter 3).

50. Pollack (2006, pp. 116-117)

51. Gutner (1999).

52. The Iraqi Trade Minister in 2004, for example, openly argued against the purchase of inferior quality domestically produced grain (see ICG, 2004, p. 14, fn. 151).

53. ICG (2004, pp. 11-13) 


\section{References}

Alnasrawi, A. 1994. The Economy of Iraq. London: Greenwood Press.

Alnasrawi, A. 2002. Iraq’s Burdens: Oil, Sanctions and Underdevelopment. London: Greenwood Press.

Brookings Institution. (Undated). "Iraq Index: Tracking Variables of Reconstruction \& Security in Post-Saddam Iraq.” <http://www.brookings.edu /fp/saban/iraq/index.pdf > [accessed 25 January 2006]

[CSIS] Center for Strategic and International Studies. 2004. "Progress or Peril? Measuring Iraq's Reconstruction.” <http://www.csis.org/isp/pcr/iraq_funds .pdf> [assessed 23 October 2005].

[CSO ]Central Statistical Organization. (Undated). Annual Abstract of Statistics 2001. Baghdad: CSO

Fine, B. 1997. "Privatization: Theory and Lessons from the U.K. and South Africa.” Seoul Journal of Economics. Vol. 10, No. 4, pp. 373-414.

Foote, C., W. Block, K. Crane, and S. Gray. 2004. "Economic Policy and Prospects in Iraq.” Journal of Economic Perspectives. Vol. 18, No. 3, pp. 47-70.

Gazdar, H. and A. Hussain. 2002. "Crisis and Response: A Study of the Impact of Economic Sanctions in Iraq,” pp. 30-83 in K.A. Mahdi, ed. Iraq's Economic Predicament. Reading, UK: Ithaca Press.

Griffin, K. 1996. Studies in Globalization and Economic Transitions. New York: St. Martin's Press.

Griffin, K. and T. McKinley. 1994. Implementing a Human Development Strategy. New York: St. Martin's Press.

Howley, J. 2004. "The Iraq Jobs Crisis.” Education for Peace in Iraq Center. Issue Brief No. 1 $<$ http://www.transafricaforum.org/documents/EPIClabor report.pdf $>$ [accessed 20 December 2005].

[ICG] ]International Crisis Group. 2004. "Reconstructing Iraq.” ICG Middle East Report No. 30.2 September 2004. Amman/Baghdad/Brussels: ICG.

[IMF] International Monetary Fund. 2003. Iraq: Macroeconomic Assessment. <http://www.imf.org/ external/np/oth/102103.pdf> [accessed 8 October 2005].

[IMF] International Monetary Fund. 2005. Iraq Staff Report for the Article IV Consultation. $<$ http://www.export.gov/iraq/pdf/imf_report_0805.pdf> [accessed 15 October 2005].

[IMF] International Monetary Fund. 2005a. Iraq: Statistical Appendix. Report No. 05/295. $<$ http://www.imf.org/external/pubs/ft/scr/2005/cr05295.pdf> [accessed 5 October 2005].

Janabi, A. 2004. “Iraqi intellectuals flee 'death squads.”' Aljazeera. 30 March 2004 <http://english.aljazeera.net/NR/exeres/FBE0836E-F273-4A36-8347-66BE05F39475.htm> [accessed 24 January 2006].

Le Billon, P. 2005. “Corruption, Reconstruction and Oil Governance in Iraq.” Third World Quarterly. Vol. 26, No. 4/5, pp. 685-703.

Little, I., T. Scitovsky, and M. Scott. 1970. Industry and Trade in some Developing Countries: A Comparative Study. Oxford: Oxford University Press.

Mullit, G. 2006. “Contractual Rip-off: The Cost of PSAs to Iraq.” EPS Quarterly. Vol. 18, No. 1.

Omran, M. 2004. "The Performance of State-Owned Enterprises and Newly Privatized Firms: Does Privatization Really Matter?” World Development. Vol. 32, No. 6, pp. 1019-1041.

Pollack, K. 2006. “A Switch in Time: A New Strategy for America in Iraq.” Analysis Paper No. 7. Washington, DC: Brookings Institute.

Ram Mohan, T.T. 2005. Privatization in India. New York: Routledge.

Richards, A. and J. Waterbury. 1998. A Political Economy of the Middle East. Boulder, CO: Westview Press.

Roberts, L., R. Lafta, R. Garfield, J. Khudairi, and G. Burnham. 2004. "Mortality Before and After the 2003 Invasion of Iraq: Cluster Sample Survey.” The Lancet. Vol. 364 (20 November 2004), pp. 1857-1864.

Sletten, P. 2005. "Unemployment in Iraq After the War.” The Middle East Economics Association roundtable on Iraq. Allied Social Sciences Association annual meeting, Boston, 6 January 2005
Struck, D. 2006. “'Brain drain’ in Iraq as professionals flee.” Washington Post. 23 January 2006 <http://www.msnbc.msn.com/id/10982329/> [accessed 24 January 2006].

Gutner, T. 1999. "The Political Economy of Food Subsidy Reform in Egypt.” Discussion Paper No. 77. Washington, DC: International Food Policy Research Institute.

Weisman, J. 2004. "US Plans to Divert Iraq Money." Washington Post. 15 September 2004 <http://www.washingtonpost.com/wp-dyn/articles/A21489-2004Sep14.html> [accessed 20 December 2005].

World Bank. 2004. World Development Report. New York: Oxford University Press, New York.

[UNDP] United Nations Development Program. 2005. Iraq Living Conditions Survey 2004. Vols. 1, 2. Baghdad: UNDP.

[UPI] United Press International. 2004. "Iraq Unemployment Drops Despite Violence." $<$ http://washingtontimes.com/upi-breaking/20041204-061822-5610r.htm> [accessed 20 December 2005].

[U.S.] U.S. Department of State. 2005. “Iraq Weekly Status Report.” 28 September 2005 $<$ http://www.state.gov/documents/organization/54230.pdf> [accessed 20 December 2005].

Vick, K. 2004. "Children Pay Cost of Iraq's Chaos.” Washington Post. 21 November 2004 $<$ http://www.washingtonpost.com/wp-dyn/articles/A809-2004Nov20.html?sub=AR> [accessed 26 January 2006].

Yousif, B. 2006. "Coalition Economic Policies in Iraq: Motivations and Outcomes.” Third World Quarterly. Vol. 27, No. 3, pp. 491-505. 